\begin{tabular}{|c|c|c|}
\hline & Benha Veterinary Medical Journal & 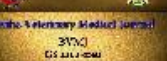 \\
\hline $\begin{array}{l}\text { Official Journal Issued by } \\
\text { Faculty of } \\
\text { Veterinary Medicine }\end{array}$ & Journal homepage: https://bvmj.journals.ekb.eg/ & $\begin{array}{l}w= \\
-=0 \\
\text { Since } 1990\end{array}$ \\
\hline
\end{tabular}

\title{
Antimicrobial effects of some essential oils and honey on some pathogenic bacteria in chicken meat
}

\author{
Amani, M. Salem ${ }^{1}$, Ahmed A. A. Maarouf ${ }^{2}$, Shimaa, M. Rashad ${ }^{3}$

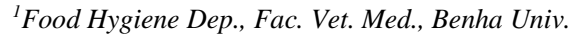 \\ ${ }^{2}$ Animal Health Research Institute, "Benha branch "ARC \\ ${ }^{3}$ Veterinarian
}

\section{ARTICLE INFO}

Keywords

Chicken meat.

E. coli

Essential oils

Honey

Received 02/06/2020

Accepted 06/07/2020

Available On-Line

$01 / 10 / 2020$

\begin{abstract}
The present study was designed to investigate antimicrobial activity of garlic (Allium sativum), thyme (Thymus vulgaris) oils at concentrations (1\%) and honey (10\%) in chicken meat. A total of $2000 \mathrm{~g}$ of the fresh chicken meat samples were divided into two groups (A\&B) the first group was inoculated with $E$. coli $\left(10^{6} \mathrm{cfu} / \mathrm{g}\right)$ and the second one with $S$. aureus $\left(10^{6} \mathrm{cfu} / \mathrm{g}\right)$ strains. Both of them were subdivided into untreated(control) and treated ones with garlic $(1 \%)$, thyme $(1 \%)$ oils and honey $(10 \%)$, respectively. All samples were stored at $4^{\circ} \mathrm{C}$ and subjected to sensory and bacteriological evaluations after 3 hours, $1^{\text {st }}, 2^{\text {nd }}$, $3^{\text {rd }}, 4^{\text {th }}$ and $5^{\text {th }}$ day of cold storage. Sensory attributes of different treated chicken meat samples were mostly improved with honey $(10 \%)$ followed by thyme oil $(1 \%)$ then garlic oil (1\%) when compared with control. Garlic oil (1\%) with reduction \% of E.coli \& S. aureus $(83.43,93.43,98.16,99.91$ and $100 \%),(86.43,98.45,99.8299 .99$ and $100 \%)$ after $1^{\text {st }}$, $2^{\text {nd }}, 3^{\text {rd }}, 4^{\text {th }} \& 5^{\text {th }}$ days of storage, respectively. While thyme oil $(1 \%)$ with reduction $\%$ of E.coli \& S. aureus $(90.18,98.58,99.90,99.99 \%$ and $100 \%),(94.35,99.69,99.95 \%$, $100 \%$ and $100 \%$ ) after $1^{\text {st }}, 2^{\text {nd }}, 3^{\text {rd }}, 4^{\text {th }} \& 5^{\text {th }}$ days of storage, respectively. The best effectiveness of both pathogens reduction $(100 \%)$ was honey $(10 \%)$ at $3^{\text {rd }}, 4^{\text {th }}$ and $5^{\text {th }}$ days, with a significant advantage in extend shelf-life of refrigerated chicken meat compared to all groups specially control ones. active principles in honey as bactericidal effect are hydrogen peroxide, phenolic acids, flavonoids and methylglyoxal. Generally, essential oils \& honey proved to be efficient natural preservatives which is safe to human than chemical ones
\end{abstract}

\section{INTRODUCTION}

Poultry meat is one of the most popular food worldwide because of its easy digestibility; acceptance by the majority of people and solve the problem of the shortage in fresh meat of high price that is not within the reach of large numbers of families with limited income (Biesalski, 2005 and Sousa, 2008). Chicken meat was a common vehicle of pathogenic microorganisms such as E. coli and $S$. aureus that considered as the most important causes of foodborne outbreaks in people (Noori and Alwan, 2016).

Avian strains of $E$. coli show many similarities with human extra intestinal pathogenic E. coli (ExPEC) strains, in that most of the virulence genes they possess and they can be transferred to humans through consumption of contaminated food or food products causing a variety of infections (Moulin et al., 2006; Johnson et al., 2006 and Ewers et al., 2007).

Staphylococcus aureus is considered the third-most important cause of food-borne disease in the world (Liu et al., 2006 and Normanno et al., 2007). The isolates from chicken carcasses showed proteolytic and lipolytic activity at $20^{\circ} \mathrm{C}$, causing meat spoilage (Gundogan and Devren, 2010).

Pathogens difficult to be eliminated during food processing, as many types of bacteria can adhere to food surface forming biofilms where they can survive even with sufficient methods of decontamination (Mohsenipour and Hassanshahian, 2015). Moreover, the old methods of food preservation have been changed to recent ones for example biochemical, bio preservatives and non-thermal (Zhou et al., 2010).

Essential oils considered excellent natural preservatives instead of chemical ones and their use in food meets the demands of consumers for mildly processed or natural products (Burt, S., 2004).

Garlic oil has antibacterial effect, as this oil rich in organ sulfur compounds which inhibit growing of many bacteria such as E. coli \& S. aureus and subsequently increase the shelf life as well as enhance the organoleptic characteristics of meat (Jolly and Menon, 2015) .

Thyme oil can be used as natural meat preservatives with antimicrobial activities against food borne pathogens, and therefore may be used in maintaining the meat quality, extending shelf life of meat products, preventing economic loss and providing the consumer with food containing natural additive (Salem et al. 2017)

In addition, the present study suggested the use of honey as a new natural substance for preservation of chicken meat and was selected on bases of its availability and its efficacy

* Corresponding author: Shimaa, M. Rashad, shimaa.rashad12@gmail.com 
as antibacterial Sulaiman et al., 2012), antifungal (Molan, 1992) and antiviral (Ghapanchi et al., 2011) beside its efficiency in controlling human pathogens (Al-Waili, 2004; Mandal and Mandal, 2011 and Albaridi, 2019).

So, the aim of this study was the evaluation of the efficiency of some essential oils (thyme \& garlic) and honey in control of E. coli and S. aureus growth in fresh chicken meat stored at $4^{\circ} \mathrm{C}$.

\section{MATERIAL AND METHODS}

\subsection{Bacterial strains:}

Actually, E. coli and S. aureus strain were obtained from Cairo- MIRCEN (Microbiological Resource Center), Faculty of Agriculture, Ain-Shams University, Egypt, with recommended dose $\left(10^{6} \mathrm{cuf} / \mathrm{ml}\right)$ for $E$. coli (Jagadeesh Babu et al., 2013) and $\left(10^{6} \mathrm{cuf} / \mathrm{ml}\right)$ for $S$. aureus (Stewart et al., 2003).

\subsection{Antibacterial agents:}

2.2.1. Natural oils:

Garlic (Allium sativum) and Thyme (Thymus vulgaris) oils (1\%) were purchased from were purchased from Elgamhoria Co., Sharkia, Egypt and stored at $4{ }^{\circ} \mathrm{C}$ until use.

\subsubsection{Pure Egyptian honey (Baladi Honey Apiary).}

2.3. Experimental application:

A total of $2000 \mathrm{~g}$ of the fresh chicken meat was purchased from retail chicken shops in Kaliobia Governorate, Egypt. The collected samples were divided into 2 main groups (1000 g of each) (A \& B) the first group was inoculated with $E$. coli $\left(10^{4} \mathrm{cfu} / \mathrm{g}\right)$ and the second one with $S$. aureus $\left(10^{6} \mathrm{cfg}\right)$ strains. Both of them were subdivided into untreated (control) and treated ones (250 g. in each) with garlic (1\%), thyme (1\%) oils and honey (10\%), respectively. All samples were stored at $4^{\circ} \mathrm{C}$ and subjected to sensory and bacteriological evaluations after 3 hours, 1 , 2, 3, 4 \& 5 days of cold storage. The experiment was performed in triplicate.

\subsection{Sensory examination:}

The color, odor and overall acceptability were determined for each sample of meat according to (Fik and Fik, 2007).

2.5. Enumeration of E. coli and S. aureus:

The counts were determined according to FDA (2002).

2.6. Reduction percentage

$$
\text { Reduction }=\frac{\text { Intial load }- \text { New Count }}{\text { Intital load }} \times 100
$$

\subsection{Statistical analysis}

Data found were analyzed as stated by Snedecor and

Cochran (1969) using the computer software program (SPSS, 2001).

\section{RESULTS}

Results in table (1) illustrated the effects of different concentrations of garlic, thyme oils \& honey on sensory attributes \& overall acceptability of artificially inoculated chicken meat samples with $E$. coli and $S$. aureus. Garlic $(1 \%)$, thyme $(1 \%)$ oils and honey $(10 \%)$ showed overall acceptability extend to $4^{\text {th }}$ and $5^{\text {th }}$ days, while control (untreated subgroups) remain accepted until $2^{\text {nd }}$ days of storage.

Table 1 . The effects of different concentrations of garlic, thyme and honey on overall acceptability of chicken meat samples stored at $4^{\circ} \mathrm{C}(\mathrm{n}=5)$.

\begin{tabular}{|c|c|c|c|c|c|c|}
\hline \multirow[t]{2}{*}{ Groups } & \multicolumn{6}{|c|}{ Storage time } \\
\hline & $3 \mathrm{hrs}$. & 1 st day & 2nd day & $3^{\text {rd }}$ day & $4^{\text {th }}$ day & $5^{\text {th }}$ day \\
\hline Control & $4.91 \pm 0.18^{\mathrm{a}}$ & $4.33 \pm 0.28^{\mathrm{a}}$ & $3.22 \pm 0.20^{\mathrm{a}}$ & $2.79 \pm 0.10^{\mathrm{b}}$ & $1.67 \pm 0.08^{\mathrm{b}}$ & $1.11 \pm 0.05^{\mathrm{c}}$ \\
\hline Garlic oil $1 \%$ & $4.93 \pm 0.10^{\mathrm{a}}$ & $4.60 \pm 0.30^{\mathrm{a}}$ & $4.36 \pm 0.19^{\mathrm{a}}$ & $4.11 \pm 0.16^{\mathrm{a}}$ & $3.69 \pm 0.18^{\mathrm{a}}$ & $2.46 \pm 0.10^{\mathrm{ab}}$ \\
\hline Thyme oil $1 \%$ & $4.96 \pm 0.12^{\mathrm{a}}$ & $4.89 \pm 0.24^{\mathrm{a}}$ & $4.73 \pm 0.12^{\mathrm{a}}$ & $4.41 \pm 0.20^{\mathrm{a}}$ & $3.81 \pm 0.18^{\mathrm{a}}$ & $3.26 \pm 0.13^{\mathrm{a}}$ \\
\hline Honey $10 \%$ & $4.99 \pm 0.17^{\mathrm{a}}$ & $4.99 \pm 0.34^{\mathrm{a}}$ & $4.97 \pm 0.27^{\mathrm{a}}$ & $4.89 \pm 0.22^{\mathrm{a}}$ & $4.58 \pm 0.18^{\mathrm{a}}$ & $4.13 \pm 0.27^{\mathrm{a}}$ \\
\hline
\end{tabular}

Score System for Sensory Evaluation: 5: Very good. 4: Good, 3: Acceptable, 2: Unacceptable, 1: Bad, S: Spoiled

As shown in table (2) results revealed the antimicrobial effects and reduction percentages of garlic, thyme oils at concentration $(1 \%)$ and honey $(10 \%)$ on counts of E. coli artificially inoculated into fresh chicken meat. Garlic oil (1\%) decreased count of $E$. coli from $4 \times 10^{6}$ (initial load) to $3.87 \pm 0.39 \times 10^{6}, 6.63 \pm 0.31 \times 10^{5}, 2.63 \pm 0.57 \times 10^{5}, 7.36 \pm 0.44 X 10^{4}$ and $3.72 \pm 0.14 \times 10^{3}(\mathrm{cfu} / \mathrm{g})$ with reduction percentages of $3.25,83.43,93.43,98.16,99.91$ and $100 \%$ after $3 \mathrm{hrs} . \& 1^{\text {st }}, 2^{\text {nd }}, 3^{\text {rd }}$, $4^{\text {th }} \& 5^{\text {th }}$ days of storage. Also, thyme oil (1\%) decreased counts of E.coli to $3.41 \pm 0.16 \times 10^{6}, 3.93 \pm 0.17 \times 10^{5}, 5.68 \pm 0.54$ $\mathrm{X} 10^{4}, 4.11 \pm 0.16 \times 10^{3}$ and $1.17 \pm 0.09 \times 10^{2}(\mathrm{cfu} / \mathrm{g})$ after $3 \mathrm{hrs} . \& 1^{\text {st }}, 2^{\text {nd }}, 3^{\text {rd }}, 4^{\text {th }} \& 5^{\text {th }}$ days of storing time, with reduction percentages of $14.75,90.18,98.58,99.90,99.99 \%$ and $100 \%$. Honey $(10 \%)$ decreased counts of E. coli after 3 hrs. , $1^{\text {st }}$ and $2^{\text {nd }}$ days of storage to $3.14 \pm 0.44 \times 10^{6}, 2.89 \pm 0.54 \times 10^{4}$ and $6.37 \pm 0.18 \times 10^{3}$ (cfu/g) with reduction percentages of 21.5, 99.28 and $99.84 \%$, with complete reduction $(100 \%)$ of $E$. coli count at $3^{\text {rd }}, 4^{\text {th }}$ and $5^{\text {th }}$ days of storage. Moreover, all results showed a significant $\mathrm{P}<0.05$ reduction (growth inhibition) of $E$. coli in chicken meat samples treated with honey $10 \%$; thyme oil $1 \%$ and garlic oil $1 \%$ during cold storage.

Table (3) declared the antimicrobial effects and reduction percentage of garlic, thyme oils at concentration (1\%) and honey $(10 \%)$ on growth of $S$. aureus artificially inoculated into fresh chicken meat. Garlic oil( $1 \%)$ decreased count of $S$. aureus from $4 \times 10^{6}$ (initial load) to $3.63 \pm 0.14 \times 10^{6}, 5.43 \pm 0.24 \times 10^{5}, 6.21 \pm 0.32 \times 10^{4}, 7.14 \pm 0.28 \times 10^{3}$ and $2.14 \pm 0.28 \times 10^{2}$ (cfu/g) with reduction percentages of $9.25,86.43,98.45,99.8299 .99$ and $100 \%$ after $3 \mathrm{hrs} \& 1^{\text {st }}, 2^{\text {nd }}, 3^{\text {rd }}, 4^{\text {th }} \& 5^{\text {th }}$ days of storing time, respectively. Moreover, thyme oil (1\%) decreased counts of $S$. aureus to $2.89 \pm 0.61 \times 10^{6}, 2.26 \pm 0.13 \times 10^{5}, 1.26 \pm 0.13$ $\mathrm{X} 10^{4}$ and $1.92 \pm 0.04 \times 10^{3}(\mathrm{cfu} / \mathrm{g})$ with reduction percentage $27.75,94.35,99.69,99.95 \%, 100 \%$ and $100 \%$ of $S$. aureus count $3 \mathrm{hrs}$. \& $1^{\text {st }}, 2^{\text {nd }}, 3^{\text {rd }}, 4^{\text {th }} \& 5^{\text {th }}$ days of storing time. At the same time, honey (10\%) decreased counts of $S$. aureus to $2.55 \pm 0.21 \times 10^{6}, 1.79 \pm 0.65 \times 10^{4}$ and $3.92 \pm 0.37 \times 10^{3}(\mathrm{cfu} / \mathrm{g})$ with reduction percentages of $36.25,99.55,99.9,0 \%, 100 \%$, $100 \%$ and $100 \%$ of S. aureus count after $3 \mathrm{hrs} . \& 1^{\text {st }}$ and $2^{\text {nd }} 3^{\text {rd }}, 4^{\text {th }} \& 5^{\text {th }}$ days of time. Moreover, there was a significant difference at $(\mathrm{P}<0.05)$ 
Table 2 The effects and Reduction percentage of various concentrations of garlic, thyme and honey on E. coli counts (cfu/g) inoculated into chicken meat

\begin{tabular}{|c|c|c|c|c|c|c|c|c|}
\hline \multirow[t]{2}{*}{ Storage time } & \multicolumn{2}{|l|}{ Control } & \multicolumn{2}{|c|}{ Garlic oil 1\% } & \multicolumn{2}{|c|}{ Thyme oil 1\% } & \multicolumn{2}{|c|}{ Honey $10 \%$} \\
\hline & Count & Reduction \% & Count & Reduction \% & Count & Reduction \% & Count & Reduction \% \\
\hline Initial load & $4.0 \times 10^{6} \pm 0.1 \times 10^{6}$ & - & $4.0 \times 10^{6} \pm 0.1 \times 10^{6}$ & - & $4.0 \times 10^{6} \pm 0.1 \times 10^{6}$ & - & $4.0 \times 10^{6} \pm 0.1 \times 10^{6}$ & - \\
\hline $3 \mathrm{hrs}$ & $4.83 \pm 0.27 \times 10^{6}$ & - & $3.87 \pm 0.39 \times 10^{6}$ & 3.25 & $3.41 \pm 0.16 \times 10^{6}$ & 14.75 & $3.14 \pm 0.44 \times 10^{6}$ & 21.5 \\
\hline 1 day & $4.28 \pm 0.26 \times 10^{6}$ & - & $6.63 \pm 0.31 \times 10^{5}$ & 83.43 & $3.93 \pm 0.17 \times 10^{5}$ & 90.18 & $2.89 \pm 0.54 \times 10^{4}$ & 99.28 \\
\hline 2nd day & $1.59 \pm 0.12 \times 10^{7}$ & & $2.63 \pm 0.57 \times 10^{5}$ & 93.43 & $5.68 \pm 0.54 \times 10^{4}$ & 98.58 & $6.37 \pm 0.18 \times 10^{3}$ & 99.84 \\
\hline 3rd day & $2.97 \pm 0.19 \times 10^{7}$ & & $7.36 \pm 0.44 \times 10^{4}$ & 98.16 & $4.11 \pm 0.16 \times 10^{3}$ & 99.9 & Not Detected & 100 \\
\hline 4th day & $8.33 \pm 0.46 \times 10^{7}$ & & $3.72 \pm 0.14 \times 10^{3}$ & 99.91 & $1.17 \pm 0.09 \times 10^{2}$ & 99.99 & Not Detected & 100 \\
\hline 5 th day & Spoiled & & Not Detected & 100 & Not Detected & 100 & Not Detected & 100 \\
\hline $\begin{array}{l}\text { Table (3) The } \\
\text { samples. }\end{array}$ & ts and Reduction p & centage & us concentration & garlic, th & $\mathrm{d}$ honey on $s . a$ & $s$ counts & noculated into & $n$ meat \\
\hline \multirow[t]{2}{*}{ Storage time } & \multicolumn{2}{|l|}{ Control } & \multicolumn{2}{|c|}{ Garlic oil $1 \%$} & \multicolumn{2}{|c|}{ Thyme oil 1\% } & \multicolumn{2}{|c|}{ Honey $10 \%$} \\
\hline & Count & $\mathrm{R} \%$ & Count & $\mathrm{R} \%$ & Count & $\mathrm{R} \%$ & Count & $\mathrm{R} \%$ \\
\hline Initial load & $4.0 \times 10^{6} \pm 0.1 \times 10^{6}$ & - & $4.0 \times 10^{6} \pm 0.1 \times 10^{6}$ & - & $4.0 \times 10^{6} \pm 0.1 \times 10^{6}$ & - & $4.0 \times 10^{6} \pm 0.1 \times 10^{6}$ & - \\
\hline $3 \mathrm{hrs}$ & $4.15 \pm 0.10 \times 10^{6}$ & & $3.63 \pm 0.14 \times 10^{6}$ & 9.25 & $2.89 \pm 0.61 \times 10^{6}$ & 27.75 & $2.55 \pm 0.21 \times 10^{6}$ & 21.5 \\
\hline 1 day & $9.64 \pm 0.36 \times 10^{6}$ & & $5.43 \pm 0.24 \times 10^{5}$ & 86.43 & $2.26 \pm 0.13 \times 10^{5}$ & 94.35 & $1.79 \pm 0.65 \times 10^{4}$ & 99.28 \\
\hline 2nd day & $5.75 \pm 0.19 \times 10^{7}$ & & $6.21 \pm 0.32 \times 10^{4}$ & 98.45 & $1.26 \pm 0.13 \times 10^{4}$ & 99.69 & $3.92 \pm 0.37 \times 10^{3}$ & 99.84 \\
\hline 3rd day & $4.82 \pm 0.36 \times 10^{8}$ & & $7.14 \pm 0.28 \times 10^{3}$ & 99.82 & $1.92 \pm 0.04 \times 10^{3}$ & 99.95 & Not Detected & 100 \\
\hline 4th day & Spoiled & & $2.14 \pm 0.28 \times 10^{2}$ & 99.99 & Not Detected & 100 & Not Detected & 100 \\
\hline 5 th day & Spoiled & & Not Detected & 100 & Not Detected & 100 & Not Detected & 100 \\
\hline
\end{tabular}

\section{DISCUSSION}

The presence of $E$. coli in food is considered as indicator of faults during preparation, handling or storage. It is also, considered as indicator of fecal contamination, beside. It may induce severe diarrhea in infants and young children, as well as food poisoning and gastroenteritis among the adults (Hassan, 2007). Further, S. aureus is an important reason of food poisoning because of eating food containing staphylococcal enterotoxins. Many types of foods are considered an excellent medium for $S$. aureus especially meat products (Guven et al., 2010).

Essential oils inhibit DNA, RNA, proteins and polysaccharides synthesis in the bacterial cells (Akthar et al., 2014). Likewise, they affect membrane integrated and associated enzyme-proteins, inhibit their production.

Tables $(2 \& 3)$ indicated that considered essential oils have a significant uncontaminated effect on $E$. coli and $S$. aureus growth, where, thyme (1\%) had higher inhibitory effect than that obtained by garlic (1\%). Used essential oils can be chosen for use as potential antibacterial efficient and extend shelf life of fresh chicken meat. These findings were similar with those of Jolly and Menon (2015), who reported that garlic possess a good potential to act as natural preservative against $E$. coli.

The tested essential oils were more effective on Gram +ve $S$. aureus than Gram -ve E. coli this may be because of that volatile action of essential oils and absence of lipopolysaccharide layer in Gram positive bacteria which consider a good barrier against any external biomolecule. Also, it may be due to that essential oils can perfectly prevent bacterial respiration and rise the plasma membrane permeability, this resulted in bacterial cells death (Burt, 2004; Wolde et al., 2018). Also, these results may be attributed to the antibacterial effect of thyme because it contains high thymol content which altering the permeability features of $E$. coli and $S$. aureus membrane. Thymol is more inhibitive at $\mathrm{pH} 5.5$ than 6.5 . At low $\mathrm{pH}$ its molecule would be un-dissociated and more hydrophobic.

So, it can bind better to the hydrophobic parts of proteins and liquify better in the lipid phase ( Helmy, Shahinaz,
2012; Küçükbay et al., 2014; Zengin and Baysal, 2015). Garlic oil has antibacterial effects, as it contain high amount of organo-sulfur compounds and their precursors which inhibit growing of most microbes like $E$. coli and $S$. aureus, increase shelf life of food, therefore it consider effective as natural preservative to chicken meat products. Addition of garlic extracts improves color, phospholipid and bacterial safety of foods (Chand, 2013; Jolly and Menon, 2015; Wolde et al., 2018). On the other hand, honey $(10 \%)$ showed the higher antibacterial effect than thyme and garlic oil (1\%). The chicken meat samples treated with honey $10 \%$ had the highest reduction rate of $E$. coli \& $S$. aureus counts.

The results of Honey treated group was similar to those of Mundo et al. (2004) and Istrati et al. (2011) as they recorded that, marination of meat with honey resulting in inhibition the growth of foodborne pathogens and maintain the shelf-life of the meat. In addition, conceded the results of Kwakman and Zaat (2011) and Matzen et al. (2018) that honey had inhibitory effects against most Gram-positive and negative bacteria specially $S$. aureus and $E$. coli, but it had more effects on Gram-positive bacteria than Gram-ve ones. The antibacterial activity of honey may be attributed to the hydrogen peroxide produced and accumulated in diluted honey either with water or tissue fluids by honey enzyme glucose oxidase during its action on honey glucose to form gluconolactone (Molan, 1996; Cooper et al., 2002; Kačániová et al., 2011). The high osmotic pressure and potassium content of honey that leads to withdrawal of water and plasmolysis of the organisms (Cooper et al., 2002; Sulaiman et al., 2012).

\section{CONCULSION}

Finally, the present study allowed to conclude that honey (10\%) proved to be more efficient than garlic and thyme oils (1\%) in suppression of both of E. coli and S. aureus growth in chicken meat. So, the use of honey $(10 \%)$, as it is safe antibacterial agent, is therefore recommended to improve safety of chicken meat products 


\section{REFERENCES}

1. Akthar.MS, Degaga.B., Azam.T., 2014. Antimicrobial activity of essential oils extracted from medicinal plants against the pathogenic microorganisms: A review. Biological Sciences and Pharmaceutical Research 2 (2014): 1-7.

2. Albaridi, Najla, A., 2019. Antibacterial Potency of Honey. International Journal of Microbiology, Article ID 2464507:110.

3. Al-Waili, N.S., 2004. Investigating the antimicrobial activity of natural honey and its effects on the pathogenic bacterial infections of surgical wounds and conjunctiva. Journal of Medicinal Food, 7, (2): 210-222.

4. Biesalski, H.K., 2005. "Meat as a component of a healthy diet. Are there any risks or benefits if meat is avoided in the diet? Meat Science, 70: 509-524.

5. Burt, S., 2004. Essential oils: Their antibacterial properties and potential applications in foods-a review. International Journal of Food Microbiology, 94:223- 253.

6. Chand, B., 2013. Antibacterial effect of garlic (Allium sativum) and ginger (Zingiber officinale) against Staphylococcus aureus, Salmonella Typhi, Escherichia coli and Bacillus cereus. J. Microbiology, Biotechnology and Food Sciences, 2 (4) 2481-2491.

7. Ewers, C., Li, G., Wilking-Kiessling, S., Alt, K., Antao, E. M., 2007. Avian pathogenic, Uropathogenic, and newborn meningitis-causing Escherichia coli: how closely related are they? Int. J. Med. Microbiol., 297:163-176.

8. Ghapanchi, J., Moattari, A., Tadbir, A.A., Talatof, Z., shahidi, S., Ebrahimi, H., 2011. The In Vitro Anti-Viral Activity of Honey on Type 1 Herpes Simplex Virus. Aust. J. Basic \& Appl. Sci., 5(12): 849-852.

9. Gundogan, N., Devren, A., 2010. Protease and lipase activity of Staphylococcus aureus obtained from meat, chicken and meatball samples. Gu J Sc., 23 (3): 381-384.

10. Guven, K., Mutlu,B.M., Gulbandilar, A., Cakir, P., 2010 Occurrence and characterization of Staphylococcus aureus isolated from meat and dairy products consumed in Turkey. $\mathbf{J}$ Food Safety, 30: 196-212.

11. Hassan-Aisha, H.A., 2007. Microbial evaluation of some cooked and half cooked chicken products with special reference to the enterotoxigenic Staph. aureus. Ph.D. Thesis (Meat Hygiene), Fac. Vet. Med. Zagazig University, Benha Branch.

12. Helmy, Shahinaze, A., 2012. Extending the shelf life of minced meat by some essential oils under refrigeration and freezing storage. International Journal of Academic Research, 4(6):14-21.

13. Hyldgaard, M., Mygind, T., Meyer, R.L., 2012. Essential oils in food preservation: mode of action, synergies, and interactions with food matrix component. Front Microbiology, 3:12.

14. Jagadeesh- Babu, A., Rupasundari, A., B., Sankar- Reddy, B., Sravanthi, M., 2012. Studies on the antimicrobial effectiveness of essential oils of garlic, clove and cinnamon on Staphylococcus aureus in chicken meat patties. Tamilnadu, J. Veterinary and Animal Sciences, 8 (1) 45-49.

15. Jenkins.R., Burton.N., Cooper.R. 2002. Proteomic and genomic analysis of methicillin-resistant staphylococcus aureus (MRSA) exposed to manuka honey in vitro demonstrated down-regulation of virulence markers. Journal of Antimicrobial Chemotherapy. 2014;69(3):603-615.

16. Johnson, J., Kuskowki, M., Menard, M., Gajewski, A., Xercavins, M., Garau, J., 2006. Similarity between human and chicken E. coli isolates in related to ciprofloxins resistance status. Infect. Dis., 194(1): 71-78.

17. Jolly, D., Menon, V., 2015. Antibacterial effect of garlic and ginger extracts on Escherichia coli and Listeria monocytogenes. International J. Applied and Pure Science and Agriculture, 1(2): 2394- 2399.

18. Salem-Amany, M., Amine-Reham, A., A. Gehan, S., 2010. Studies on Antimicrobial and Antioxidant Efficiency of Some Essential Oils in Minced Beef. Journal of American Science, 6,12 .

19. Kwakman, P.H.S., De Boer L., Ruyter-Spira, C.P., et al, 2011. Medical-grade honey enriched with antimicrobial peptides has enhanced activity against antibiotic-resistant pathogens. European Journal of Clinical Microbiology \& Infectious Diseases. 30(2): 251-257.

20. Liu, X., Chen, Y., Fan, Y., Wang, M., 2006. Foodborne diseases occurred in 2003 - report of the national foodborne diseases surveillance system, China. Chinese Journal of Hygiene Research, 35: 201-204.

21. M.D., Mandal, S. Mandal, 2011. Honey its medicinal property and antibacterial activity, Asian Pacific Journal of Tropical Biomedicine 1(2): 154-160.

22. Melissa, A. Mundo, Olga, I. Padilla-Zakour, Randy, W Worobo, 2004. Growth inhibition of foodborne pathogens and food spoilage organisms by select raw honeys. International Journal of Food Microbiology, 97(1): 1-8.

23. Mohsenipour, Z., Hassanshahian, M., 2015. The Effects of Allium sativum Extracts on Biofilm Formation and Activities of Six Pathogenic Bacteria. Jundishapur J. Microbiol., 8(8): 18971-18978.

24. Molan, P.C., Allen, K.L., 1996. The effect of gammairradiation on the antibacterial activity of honey. Journal of Pharmacy and Pharmacology 48(11):1206-1209.

25. Moulin, S.M., Schouler, C., Tailliez, P.; Kao, M. R.; Bree, A., Germon, P., 2006. Common virulence factors and genetic relationships between $\mathrm{O}_{18}: \mathrm{K}_{1}: \mathrm{H}_{7}$ Escherichia coli isolates of human and avian origin. J. Clinic. Microbiol., 44: 3484-3492.

26. Noori, T.E., Alwan, M.J., 2016. Isolation and Identification of Zoonotic Bacteria from Poultry Meat. Int. J. Adv. Res. Biol. Sci., 3(8): 57-66.

27. Normanno, G., La Salandra, G., Dambrosio, A., Quaglia, N.C., Corrente, M., Parisi, A., Santagada, G., Firin, U.A., Crisetti, E. Celano, G.V. 2007. "Occurrence, characterization and antimicrobial resistanceof enterotoxigenic Staphylococcus aureus isolated from meat and dairy products". International J. Food Microbiology, 115: 290-296

28. Snedecor, G.W., Cochran, W.G., 1969. Statistical Methods, 6th Ed. Iowa State University Press, Asmes, USA

29. Sousa, C.P., 2008. The Impact of Food Manufacturing Practices on Food borne Diseases. Brazilian Archives of Biology and Technology, 51(4), 815-823.

30. Sulaiman, A., Milton,W., Khalid, A., 2012. Antibacterial potential of honey from different origins: A comparison with Manuka honey. J. Microbiology, Biotechnology and Food Sciences, 1 (5):1328-1338.

31. Wolde, T., Kuma, H., Trueha, K., Yabeker, A., 2018. AntiBacterial Activity of Garlic Extract against Human Pathogenic Bacteria. J Pharmacovigilance, 6 (1): 1-6.

32. Zengin, H., Ayse Handan Baysal, 2015. Antioxidant and Antimicrobial Activities of Thyme and Clove Essential Oils and Application in Minced Beef. Journal of food processing and preservation, View issue TOC Volume 39, Issue 6 December 2015 Pages 1261-1271.

33. Zhou, G. H., Xu, X.L., Liu, Y., 2010. Preservation technologies for fresh meat- A review. Meat Sci., 68: 119128 